\title{
Screening Rice Germplasm against Sheath Blight Disease of Rice and its Integrated Management in Bangladesh
}

\author{
S Parveen ${ }^{*}, \mathrm{M} \mathrm{A} \mathrm{Ali}^{2}$ and M A Ali ${ }^{3}$
}

\begin{abstract}
Fifty-seven rice germplasm collected from BRRI Genebank were screened against sheath blight (ShB) by artificial inoculation in field and laboratory conditions in T. Aman 2012. Significant differences on relation to lesion height (RLH) among the germplasm were observed, where the highest $(83 \%)$ was recorded in susceptible check, BR11 and the lowest $(8.33 \%)$ was in Orgoja. Severity score of ShB was recorded maximum (9) in Dudhsail, Basi, Chaula mari, Holdemota, Calendamota, Semmua, Kotijira, Halisail, Horakani, Kalisura, Ashfuli, Huglapata and BR11 as highly susceptible to ShB, whereas it was minimum (1) in Orgoja. Gopal ghosh was observed as moderately tolerant with $27.33 \%$ RLH and severity score 3, while Kala binni, Khazur chari, Binni, Kalagora, Patjait and Dorkumur found moderately tolerant with severity score 5 . In detached sheath inoculation method in test tube, most of the germplasms found highly susceptible, except Orgoja as resistant and Gopal ghosh as moderately tolerant. However, Orgoja showed resistance in both field inoculation and detached sheath inoculation methods. But, Dorkumur was found moderately tolerant in field and highly susceptible in detached sheath inoculation in laboratory. The experiment of Integrated Disease Management (IDM) packages was conducted in the farmer's field with BR11 at Fulpur, Mymensingh during T. Aman 2013. The IDM practices of rice ShB resulted profound effect. Relative lesion height, percent disease index, tiller infection and hill infection were maximum $(68 \%, 69 \%, 86 \%$ and $79 \%$ respectively) in $\mathrm{T}_{6}$ (control) and minimum in $\mathrm{T}_{1}$ [FDR (removal of floating debris) + 30 July transplanting + Potash (K) fertilizer (202 $\left.\mathrm{g} \mathrm{decimal}^{-1}\right)+$ Top dressing of urea $\left(247 \mathrm{~kg} \mathrm{ha}^{-1}\right)$ in four equal splits at 15 days interval + single spray of fungicides of Azoxystrobin 10\% (0.17 kg ha-1) + Tebuconazole $90 \%(500 \mathrm{ml}$ $\left.\mathrm{ha}^{-1}\right)$ ]. Moreover, the highest number of panicles per $\mathrm{m}^{2}$, filled grains per panicle and grains yield were recorded in $\mathrm{T}_{1}\left(160,150\right.$ and $6.25 \mathrm{t} \mathrm{ha}^{-1}$ respectively) and the minimum in $\mathrm{T}_{6}(227,120$ and $3.6 \mathrm{t}$ ha $^{-1}$ respectively). Therefore, the best IDM package was $T_{1}$ for its effective control of ShB disease as well as yield maximization of rice. Finally, Orgoja could be used in resistance breeding for varietal improvement and the IDM package of $T_{1}$ need to be recommended to prescribe in the farmer's field after simulation in different AEZs and seasons with different varieties of Bangladesh.
\end{abstract}

Key words: Germplasm, resistance, integrated management, sheath blight, rice

\section{INTRODUCTION}

Bangladesh agriculture involves food production for 163.65 million people (Salam et al., 2014), where rice is the principal food. This increasing population requires increasing crop yields for stable supply of grain to achieve food security of the country. Consequently, the national average production needs to be increased from 3 to $5 \mathrm{t} \mathrm{ha}^{-1}$ in next 20 years (Mahbub et al., 2001). In Bangladesh, rice production area is 11.01 million hectares of land during 2016-17 (BBS, 2018). However,
36.27 million metric tons of rice is produced in the country during 2017-18 (AIS, 2019). Sheath blight (ShB) of rice was first reported in Japan by Miyakie in 1910. It is caused by Rhizoctonia solani Kuhn. It is considered as the most damaging major epidemic disease of rice ( $\mathrm{Li}$ et al., 2012). ShB is an important disease of rice, especially in intensive rice production systems. The average incidence of ShB in Bangladesh is about 20.3\% (Ali et al., 2003). The yield loss caused by ShB in Bangladesh ranged from 14 to $31 \%$ under farmer's field (Shahjahan et al., 1986). The presence of one or many factors

\footnotetext{
${ }^{1}$ Senior Scientific Officer, Training Division, BRRI, Gazipur 1701, 2Professor, Department of Plant Pathology, Faculty of Agriculture, BAU, Mymensingh and 'Birector (Administration and Common Service), BRRI, Gazipur 1701. ${ }^{*}$ Corresponding author's E-mail: parveenbrri@yahoo.com.
} 
may enhance the severity of ShB beyond economic threshold levels, thereby incurring low to high yield losses.

Incidence and development of ShB of rice depends on climate, host and soil factor (Damicone et al., 1993). Short duration and semi-dwarf cultivars are more susceptible to ShB (Groth and Lee, 2002). During rice ShB epidemics, severe lodging may occur ( $\mathrm{Wu}$ et al., 2012). Differences in yield loss between very susceptible and moderately resistant cultivars are substantial. On infection by Rhizoctonia solani, semi-dwarf varieties show more than twice the reduction in yield and milling quality.

Breeding for resistance against ShB has not been successful due to lack of sources of resistant genes (Rao, 1995; Hashiba and Kobayashi, 1996). Resistance source against ShB disease of rice is not available in Bangladesh and anywhere (Jalal Uddin et al., 2000). Consequently, none of the high yielding varieties is resistant to $\mathrm{ShB}$ disease neither in Bangladesh nor elsewhere in the world. Fortunately, rice land races have proven to be highly adaptive to diverse environmental conditions and are believed to harbour a number of valuable genetic resources for crop improvement (Karmakar et al., 2012; Roychowdhury et al., 2013; Ganie et al., 2014). Some of the landraces such as Buhjan, Banshpata, Bhasamanik, Nagra Sail, Raghu Sail are tolerant to rice ShB (Dey, 2014). Therefore, local or land races of rice need to be exploited for getting resistant or moderately resistant or even better tolerant sources for ShB disease.

The control of ShB in the field so far is mainly relied on the use of fungicides, which is not sustainable for its residual effect along with the potential risk of resistant to fungicides overtime. Disease management programme against $\mathrm{ShB}$ can concentrate different approaches such as incorporating cultural practices, exploitation of host resistance, biological control with Trichoderma harzianum and Trichoderma viride and chemical control. Ashrafuzzaman et al. (2005) also reported that emphasis should be given on different management options to control ShB disease of rice. For clean cultivation, burning the crop residues, destroy grasses and other hosts from the field, collecting and burying floating debris after final land preparation may reduce infection foci. Instead of applying excess dose of nitrogen, split application of $\mathrm{K}$ fertilizer with last top dress of urea can reduce its infestation. Application of $40 \mathrm{~kg} \mathrm{MP} / \mathrm{ha}$ as top dress in two equal splits and transplanting with $20 \mathrm{~cm} \times 20 \mathrm{~cm}$ spacing have affect on ShB (Hossain and Mia, 2001). Large amount of $\mathrm{N}$ and phosphate $(\mathrm{P})$ is favourable for ShB disease (Dasgupta, 1992) and high potash (K) or PK is useful for infection (CRRI, 1977). Therefore, the present research programme was planned and designed to develop management technologies of the disease with the aim of recommending suitable control strategies in Bangladesh. The present study was under taken to screen germplasm for their reaction to $\mathrm{ShB}$ and to develop an integrated management practice for controlling ShB of rice in Bangladesh.

\section{MATERIALS AND METHODS}

\section{Screening of rice germplasm against ShB of} rice

Rice germplasm. A total of 57 rice germplasm collected from BRRI Genebank were screened against $\mathrm{ShB}$ disease of rice in the field through hill inoculation method and BR11 was used as susceptible check (Table 1). 
Table 1. Primary information of the germplasms used for screening resistance source against sheath blight.

\begin{tabular}{|c|c|c|c|c|c|}
\hline Acc. no.* & Variety & Acc. no. & Variety & Acc. no. & Variety \\
\hline 4111 & Gopal ghosh & 4794 & Kalahati & 5221 & Kalisura \\
\hline 4112 & Chata bazail & 4795 & Khajur chhori & 5222 & Akra \\
\hline 4113 & Ram dash & 4849 & Rayeda & 5223 & Ushi har \\
\hline 4114 & Paizra & 5121 & Jamni & 5250 & Ashfuli \\
\hline 4118 & Kala binni & 5122 & Chaula maghi & 5286 & Ranisalut \\
\hline 4149 & Beto & 5190 & Bushi hara (mota) & 5289 & Buripagli \\
\hline 4155 & Chini kani & 5192 & Lohamugra & 5298 & Harisankar \\
\hline 4156 & Minki & 5193 & Chaula mari & 5300 & Birinde \\
\hline 4162 & Kasrail & 5194 & Kalagora & 5310 & Orgoja \\
\hline 4163 & Khazur chari & 5195 & Patjait & 5316 & Nonamurchi \\
\hline 4239 & Binni & 5196 & Holdemota & 5319 & Gandhakusturi \\
\hline 4267 & Birpala & 5197 & Kanchachikon & 5327 & Huglapata \\
\hline 4271 & Rayda & 5198 & Dholeshwar mota & 5329 & Gota \\
\hline 4272 & Dhaki rayda & 5199 & Calendamota & 5330 & Dorkumur \\
\hline 4768 & Kaijhuri & 5212 & Semmua & 5337 & Changi \\
\hline 4773 & Dudhsail & 5213 & Kotijira & 5345 & Rasasail \\
\hline 4777 & Kashra & 5217 & Ashkor & 5347 & Sackhorkhana \\
\hline 4778 & Katarangi & 5218 & Baskor & -- & BR11 \\
\hline 4792 & Basi & 5219 & Halisail & & \\
\hline 4793 & Sada pankaich & 5220 & Horakani & & \\
\hline
\end{tabular}

* BRRI Genebank accession number.

Field experiment. The experiment was conducted at the experiment field of Bangladesh Rice Research Institute (BRRI), Gazipur during T. Aman 2012. A levee was made surrounding plots to maintain standing water up to $5.0 \mathrm{~cm}$ inside. Land was prepared 15 days before transplanting/seedling. Ploughing and cross ploughing followed by laddering was done by power tiller. Weeds were cleaned manually. The seedlings of the tested germplasms were raised in plastic tray in the Plant Pathology net house. Thirty-day-old 2-3 seedlings per hill were transplanted with a spacing of $20 \mathrm{~cm} \times 15 \mathrm{~cm}$. Fertilizers were applied @ 405: 150: 202: 135: $10 \mathrm{~g}$ decimal-1 $^{-1}$ of urea, TSP, MOP, gypsum and zinc sulphate. All fertilizers were applied in basal, except urea (Anonymous, 2010). For agronomic, weed management, irrigation and drainage and insect management current standard recommendations were followed (Anonymous, 2007).

Preparation of inoculum. One hundred PDA plates in glass petridishes were prepared following the standard procedure. The fungus (Rhizoctonia solani) was grown in the petridishes containing PDA medium and incubated for seven days at room temperature $\left(25\right.$ to $30^{\circ} \mathrm{C}$ ) for growth and development of the pathogen.

Inoculation of pathogen. Inoculations were done at maximum tillering stage (Bhaktavatsalam et al., 1978). Two methods of inoculation were employed for inoculation of germplasms by Rhizoctonia solani. After seven days of inoculation lesion length and leaf sheath length were measured and calculated. The methods were as follows:

a. Hill inoculation-Total hill were inoculated with Rhizoctonia solani Kuhn culture (7 days) grown on PDA medium. Prior to inoculation, eight hills were tagged randomly in the central area of each plot in the field for inoculation. Inoculation was done by inserting a piece of culture medium (cutting the culture medium into eight pieces) at the middle of each hill in the afternoon, colonized by the ShB pathogen in a tagged rice hill and maintained standing water onward of the crop growth to maintained high moisture below canopy level for disease development (Sharma and Teng, 1990). 
b. Detached sheath inoculation-Detached sheath was inoculated in moist test tube (Fig. 1). In detached sheath inoculation method, one tiller from each entry was taken i.e. three tillers for three replications. Tillers were cut in such a way that leaf sheath did not separate from stem or remain in contact with stem and uniform in size. Water soaked cotton was placed at the bottom of the test tube and then placed 6-9 $\mathrm{mm}$ mycelial block (growing pathogen) inside the sheath. The test tube was then plugged with soaked cotton.

Data recording. The disease severity was recorded from the data collected from 25 hills in each replication of each treatment. Severity was calculated by relative lesion height (RLH) (McKinney, 1923). Data were recorded for each treatment following standard evaluation system (SES) for rice in 0-9 scale (Anonymous, 1996). Data of the lesion height, plant height, 1000 grain weight and grain yield (g hill-1) were also recorded. In detached sheath inoculation method, ShB severity was measured by RLH using the following formula-

$$
\begin{gathered}
\text { Lesion height }(\mathrm{cm}) \\
\text { Leaf sheath height }(\mathrm{cm})
\end{gathered}
$$

\section{Integrated management of ShB of rice}

Field experiment. The experiment was conducted in the farmer's field with BR11 at Fulpur, Mymensingh during T. Aman 2013. Plant to plant spacing was $15 \mathrm{~cm}$ and row to row distance was $16 \mathrm{~cm}$. Randomized RCBD was used with four replications. Plot size was

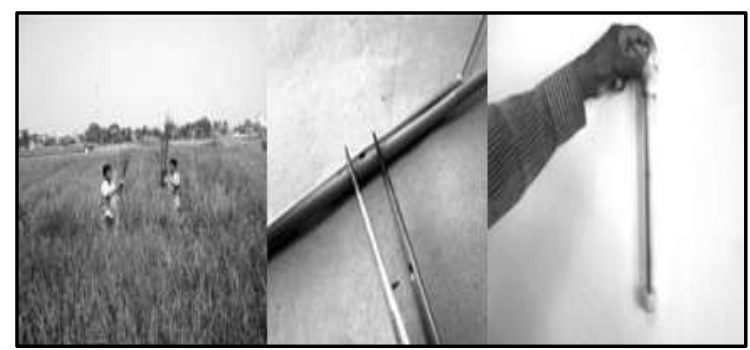

Fig. 1. Detached sheath inoculation method of screening against ShB of rice.
$2.5 \mathrm{~m} \times 4 \mathrm{~m}$. Plot to plot distance was $0.5 \mathrm{~m}$ and block to block distance was $1 \mathrm{~m}$. The best options obtained from the results of different experiments (Parveen, 2016) were included into integrated disease management (IDM) packages and were simulated in the field. The treatments used in this study were shown below:

$\mathrm{T}_{1}=\mathrm{FDR}$ (removal of floating debris) +30 July planting + Potash (K) fertilizer (202 $\mathrm{g} \mathrm{decimal}^{-}$ $\left.{ }^{1}\right)+$ Top dressing of urea $\left(247 \mathrm{~kg} \mathrm{ha}^{-1}\right)$ in four equal splits at 15 days interval + single spray of fungicide [Azoxystrobin 10\% $\left(0.17 \mathrm{~kg} \mathrm{ha}^{-1}\right)+$ Tebuconazole $90 \%$ (500 $\left.\mathrm{ml} \mathrm{ha}^{-1}\right)$ ]. $\mathrm{T}_{2}=30$ July planting + K-dose + top dressing of urea in four equal splits at 15 days interval + single spray of fungicide. $\mathrm{T}_{3}=\mathrm{K}$-dose + top dressing of urea in four equal splits at 15 days interval + single spray of fungicide. $T_{4}=$ Top dressing of urea in four equal splits at 15 days interval + single spray of fungicide. $T_{5}=$ Single spray of fungicide. $\mathrm{T}_{6}=$ Control.

Inoculation of pathogen. Same as hill inoculation method.

Data collection. Twenty-five hills were selected at random from each experimental unit. Number of infected tillers and hills were counted. Incidence was recorded by tiller infection and expressed in percentage, while severity by relative lesion height (RLH) and percent disease index (PDI) (McKinney, 1923). Data were recorded for each treatment following standard evaluation system (SES) for rice in 0-9 scale (Anonymous, 1996). Data on total tiller, infected tiller, plant height, panicle per $\mathrm{m}^{2}$, filled grain, unfilled grain, 1000 grain weight (TGW) and grain yield were also recorded. PDI was measured by using the following formula-

\section{Total rating}

PDI = - - $\times 100$

No. of observation $\times$ Maximum grade 
Statistical analysis. The data were of ShB was recorded in Dudhsail, Basi, Chaula subjected to statistical analysis and ANOVA (analysis of variance) were constructed following RCBD by SPSS 2.05 programme for both the experiments. The treatment means were compared by LSD test at probability level $\mathrm{P}=0.05$.

\section{RESULTS AND DISCUSSION}

Assessment of germplasm against ShB of rice Table 2 shows that there was a variation among the germplasms on ShB disease development and yield through hill inoculation in the field. Significant differences on RLH among the germplasms were observed. The highest RLH was recorded in BR11 (83\%) and the lowest was in Orgoja $(8.33 \%)$. The maximum (9) severity (SES) score mari, Holdemota, Calendamota, Semmua, Kotijira, Halisail, Horakani, Kalisura, Ashfuli, Huglapata and BR11, which were highly susceptible (HS) to ShB disease, whereas the minimum severity score (1) was observed in Orgoja. Gopal ghosh was observed as moderately tolerant to ShB disease with $27.33 \%$ RLH and severity score 3. Moreover, Kala binni, Khazur chari, Binni, Kalagora, Patjait and Dorkumur found moderately tolerant to ShB with severity score 5 . On the other hand, the highest yield was found in Beto (18.23 g hill-1), Rayda (18.15), Ushi har (18.23) and Buripagli (18.15) and the lowest in Kashra, Calendamota, Orgoja and Sackhorkhana (4.85 $\left.\mathrm{g} \mathrm{hill}^{-1}\right)$ germplasms (Table 3).

Table 2. Reaction of screened germplasm against ShB due to artificial inoculation of Rhizoctonia solani through hill inoculation method in the field.

\begin{tabular}{llccccc}
\hline Acc. no. & Variety & Growth duration & Plant height $(\mathrm{cm})$ & RLH $(\%)$ & SES score & Reaction \\
\hline 4111 & Gopal ghosh & 150 & 131 & 27.33 & 3 & MT \\
4112 & Chata bazail & 151 & 140 & 47.66 & 7 & HS \\
4113 & Ram dash & 152 & 144 & 54.00 & 7 & HS \\
4114 & Paizra & 149 & 127 & 63.00 & 7 & HS \\
4118 & Kala binni & 151 & 129 & 38.00 & 5 & MT \\
4149 & Beto & 155 & 154 & 53.00 & 7 & HS \\
4155 & Chini kani & 147 & 141 & 61.66 & 7 & HS \\
4156 & Minki & 156 & 141 & 61.33 & 7 & HS \\
4162 & Kasrail & 154 & 141 & 53.66 & 7 & HS \\
4163 & Khazur chari & 148 & 141 & 41.33 & 5 & MT \\
4239 & Binni & 147 & 137 & 43.66 & 5 & MT \\
4267 & Birpala & 141 & 136 & 54.33 & 7 & HS \\
4271 & Rayda & 149 & 136 & 50.33 & 7 & HS \\
4272 & Dhaki rayda & 146 & 150 & 60.00 & 7 & HS \\
4768 & Kaijhuri & 142 & 119 & 56.33 & 7 & HS \\
4773 & Dudhsail & 154 & 149 & 69.00 & 9 & HS \\
4777 & Kashra & 145 & 151 & 51.66 & 7 & HS \\
4778 & Katarangi & 145 & 115 & 64.66 & 7 & HS \\
4792 & Basi & 140 & 149 & 75.33 & 9 & HS \\
4793 & Sada pankaich & 138 & 149 & 53.66 & 7 & HS \\
4794 & Kalahati & 143 & 150 & 62.33 & 7 & HS \\
4795 & Khajur chhori & 142 & 152 & 56.66 & 7 & HS \\
4849 & Rayeda & 145 & 150 & 66.33 & 7 & HS \\
5121 & Jamni & 147 & 154 & 63.66 & 7 & HS \\
5122 & Chaula maghi & 149 & 150 & 57.00 & 7 & HS \\
5190 & Bushi hara (mota) & 150 & 55.33 & 7 & HS \\
5192 & Lohamugra & 149 & & & & HS \\
\hline
\end{tabular}


Table 2. Continued.

\begin{tabular}{|c|c|c|c|c|c|c|}
\hline Acc. no. & Variety & Growth duration & Plant height $(\mathrm{cm})$ & RLH (\%) & SES score & Reaction \\
\hline 5193 & Chaula mari & 145 & 151 & 72.66 & 9 & HS \\
\hline 5194 & Kalagora & 149 & 141 & 42.33 & 5 & MT \\
\hline 5195 & Patjait & 149 & 152 & 45.00 & 5 & MT \\
\hline 5196 & Holdemota & 150 & 146 & 68.66 & 9 & HS \\
\hline 5197 & Kanchachikon & 153 & 156 & 64.66 & 7 & HS \\
\hline 5198 & Dholeshwar mota & 154 & 165 & 60.33 & 7 & HS \\
\hline 5199 & Calendamota & 155 & 161 & 66.33 & 9 & HS \\
\hline 5212 & Semmua & 152 & 142 & 69.33 & 9 & HS \\
\hline 5213 & Kotijira & 150 & 134 & 70.00 & 9 & HS \\
\hline 5217 & Ashkor & 149 & 146 & 55.33 & 7 & HS \\
\hline 5218 & Baskor & 150 & 158 & 49.33 & 7 & HS \\
\hline 5219 & Halisail & 148 & 149 & 66.00 & 9 & HS \\
\hline 5220 & Horakani & 148 & 166 & 67.33 & 9 & HS \\
\hline 5221 & Kalisura & 149 & 144 & 74.33 & 9 & HS \\
\hline 5222 & Akra & 148 & 174 & 54.00 & 7 & HS \\
\hline 5223 & Ushi har & 152 & 144 & 52.66 & 7 & HS \\
\hline 5250 & Ashfuli & 161 & 98 & 66.66 & 9 & HS \\
\hline 5286 & Ranisalut & 165 & 147 & 59.00 & 7 & HS \\
\hline 5289 & Buripagli & 163 & 165 & 58.33 & 7 & HS \\
\hline 5298 & Harisankar & 153 & 164 & 51.33 & 7 & HS \\
\hline 5300 & Birinde & 157 & 150 & 64.66 & 7 & HS \\
\hline 5310 & Orgoja & 160 & 160 & 8.33 & 1 & $\mathrm{R}$ \\
\hline 5316 & Nonamurchi & 155 & 152 & 55.00 & 7 & HS \\
\hline 5319 & Gandhakusturi & 152 & 139 & 65.00 & 7 & HS \\
\hline 5327 & Huglapata & 154 & 147 & 73.33 & 9 & HS \\
\hline 5329 & Gota & 151 & 152 & 57.66 & 7 & HS \\
\hline 5330 & Dorkumur & 159 & 153 & 41.66 & 5 & MT \\
\hline 5337 & Changi & 151 & 151 & 55.66 & 7 & HS \\
\hline 5345 & Rasasail & 159 & 113 & 62.33 & 7 & HS \\
\hline 5347 & Sackhorkhana & 153 & 128 & 53.66 & 7 & HS \\
\hline-- & BR11 & 145 & 115 & 83.00 & 9 & HS \\
\hline \multicolumn{7}{|c|}{$\operatorname{LSD}(\mathrm{P}=0.05)$} \\
\hline
\end{tabular}

MT=Moderately tolerant, HS=Highly susceptible, R=Resistant.

Table 3. Yield and 1000 grain weight (TGW) of screened germplasms against ShB due to artificial inoculation of Rhizoctonia solani through hill inoculation in the field.

\begin{tabular}{lccc}
\hline Acc. no. & Variety & TGW (g) & Yield (g hill-1) \\
\hline 4111 & Gopal ghosh & 20.13 & 6.92 \\
4112 & Chata bazail & 21.14 & 8.17 \\
4113 & Ram dash & 24.63 & 9.05 \\
4114 & Paizra & 25.05 & 9.60 \\
4118 & Kala binni & 29.11 & 10.05 \\
4149 & Beto & 20.38 & 18.23 \\
4155 & Chini kani & 9.19 & 5.30 \\
4156 & Minki & 29.27 & 6.32 \\
4162 & Kasrail & 26.14 & 14.55 \\
4163 & Khazur chari & 21.44 & 7.24 \\
4239 & Binni & 10.22 & 8.22 \\
4267 & Birpala & 20.33 & 10.92 \\
4271 & Rayda & 24.37 & 18.15 \\
4272 & Dhaki rayda & 12.40 & 10.36 \\
4768 & Kaijhuri & 29.16 & 10.28 \\
4773 & Dudhsail & 14.03 & 10.07 \\
4777 & Kashra & 16.05 & 4.85 \\
\hline
\end{tabular}

6 Parveen et al 
Table 3. Continued.

\begin{tabular}{|c|c|c|c|}
\hline Acc. no. & Variety & TGW (g) & Yield (g hill-1) \\
\hline 4778 & Katarangi & 13.33 & 8.40 \\
\hline 4792 & Basi & 15.55 & 10.18 \\
\hline 4793 & Sada pankaich & 16.26 & 12.56 \\
\hline 4794 & Kalahati & 12.89 & 11.03 \\
\hline 4795 & Khajur chhori & 15.19 & 10.59 \\
\hline 4849 & Rayeda & 12.30 & 5.82 \\
\hline 5121 & Jamni & 20.49 & 11.91 \\
\hline 5122 & Chaula maghi & 26.87 & 16.03 \\
\hline 5190 & Bushi hara (mota) & 27.06 & 5.55 \\
\hline 5192 & Lohamugra & 27.12 & 10.17 \\
\hline 5193 & Chaula mari & 21.44 & 7.24 \\
\hline 5194 & Kalagora & 10.22 & 8.22 \\
\hline 5195 & Patjait & 20.33 & 10.92 \\
\hline 5196 & Holdemota & 19.37 & 10.15 \\
\hline 5197 & Kanchachikon & 12.40 & 10.36 \\
\hline 5198 & Dholeshwar mota & 29.16 & 10.28 \\
\hline 5199 & Calendamota & 16.05 & 4.85 \\
\hline 5212 & Semmua & 13.33 & 8.40 \\
\hline 5213 & Kotijira & 15.55 & 10.18 \\
\hline 5217 & Ashkor & 16.26 & 12.56 \\
\hline 5218 & Baskor & 12.89 & 11.03 \\
\hline 5219 & Halisail & 21.14 & 8.17 \\
\hline 5220 & Horakani & 24.63 & 9.05 \\
\hline 5221 & Kalisura & 25.05 & 9.60 \\
\hline 5222 & Akra & 29.11 & 10.05 \\
\hline 5223 & Ushi har & 20.38 & 18.23 \\
\hline 5250 & Ashfuli & 9.19 & 5.30 \\
\hline 5286 & Ranisalut & 20.33 & 10.92 \\
\hline 5289 & Buripagli & 24.37 & 18.15 \\
\hline 5298 & Harisankar & 12.40 & 10.36 \\
\hline 5300 & Birinde & 29.16 & 10.28 \\
\hline 5310 & Orgoja & 10.05 & 4.85 \\
\hline 5316 & Nonamurchi & 12.30 & 5.82 \\
\hline 5319 & Gandhakusturi & 20.49 & 11.91 \\
\hline 5327 & Huglapata & 11.87 & 5.40 \\
\hline 5329 & Gota & 27.06 & 5.55 \\
\hline 5330 & Dorkumur & 27.12 & 10.17 \\
\hline 5337 & Changi & 12.40 & 10.36 \\
\hline 5345 & Rasasail & 29.16 & 10.28 \\
\hline 5347 & Sackhorkhana & 16.05 & 4.85 \\
\hline-- & BR11 & 23.98 & 13.98 \\
\hline $\operatorname{LSD}(\mathrm{P}=0.05)$ & & 0.83 & 0.76 \\
\hline
\end{tabular}

Table 4 shows that Orgoja was resistant the two inoculation method (i.e. hill inoculation and against ShB disease of rice with the minimum RLH detached sheath inoculation) Orgoja was found as $(11.66 \%)$ and severity score (1), whereas Gopal gosh resistant and Gopal ghosh as moderately tolerant to was moderately tolerant to ShB with $40.56 \%$ RLH ShB disease. In detached sheath inoculation and severity score 5 through detached sheath method in test tube, most of the germplasms were inoculation method in test tube. But, rest of the found highly susceptible to ShB except Orgoja and germplasms with RLH ranging from 48.33 to Gopal ghosh. Dorkumur was found moderately $89.66 \%$ along with BR11 (90.68\%) (Fig. 2) were tolerant in field condition but it showed high level found highly susceptible against ShB. Comparing of susceptibility to ShB in case of detached sheath 
Table 4. Reaction of screened germplasms against ShB due to artificial inoculation of Rhizoctonia solani through detached sheath inoculation in test tube.

\begin{tabular}{|c|c|c|c|c|}
\hline Acc. no. & Variety & RLH (\%) & SES score & Reaction \\
\hline 4111 & Gopal ghosh & 40.56 & 5 & MT \\
\hline 4112 & Chata bazail & 70.33 & 9 & HS \\
\hline 4113 & Ram dash & 60.00 & 7 & HS \\
\hline 4114 & Paizra & 74.33 & 9 & HS \\
\hline 4118 & Kala binni & 72.33 & 9 & HS \\
\hline 4149 & Beto & 82.66 & 9 & HS \\
\hline 4155 & Chini kani & 61.66 & 7 & HS \\
\hline 4156 & Minki & 67.33 & 9 & HS \\
\hline 4162 & Kasrail & 58.00 & 7 & HS \\
\hline 4163 & Khazur chari & 72.66 & 9 & HS \\
\hline 4239 & Binni & 78.33 & 9 & HS \\
\hline 4267 & Birpala & 68.00 & 9 & HS \\
\hline 4271 & Rayda & 59.66 & 7 & HS \\
\hline 4272 & Dhaki rayda & 72.33 & 9 & HS \\
\hline 4768 & Kaijhuri & 63.00 & 7 & HS \\
\hline 4773 & Dudhsail & 69.00 & 9 & HS \\
\hline 4777 & Kashra & 53.00 & 7 & HS \\
\hline 4778 & Katarangi & 57.33 & 7 & HS \\
\hline 4792 & Basi & 75.33 & 9 & HS \\
\hline 4793 & Sada pankaich & 65.66 & 9 & HS \\
\hline 4794 & Kalahati & 75.00 & 9 & HS \\
\hline 4795 & Khajur chhori & 67.33 & 9 & HS \\
\hline 4849 & Rayeda & 69.66 & 9 & HS \\
\hline 5121 & Jamni & 64.66 & 7 & HS \\
\hline 5122 & Chaula maghi & 63.33 & 7 & HS \\
\hline 5190 & Bushi hara (mota) & 56.00 & 7 & HS \\
\hline 5192 & Lohamugra & 65.33 & 7 & HS \\
\hline 5193 & Chaula mari & 72.66 & 9 & HS \\
\hline 5194 & Kalagora & 65.66 & 9 & HS \\
\hline 5195 & Patjait & 63.33 & 7 & HS \\
\hline 5196 & Holdemota & 81.33 & 9 & HS \\
\hline 5197 & Kanchachikon & 73.66 & 9 & HS \\
\hline 5198 & Dholeshwar mota & 83.00 & 9 & HS \\
\hline 5199 & Calendamota & 66.33 & 9 & HS \\
\hline 5212 & Semmua & 78.00 & 9 & HS \\
\hline 5213 & Kotijira & 76.33 & 9 & HS \\
\hline 5217 & Ashkor & 55.33 & 7 & HS \\
\hline 5218 & Baskor & 64.00 & 7 & HS \\
\hline 5219 & Halisail & 66.00 & 9 & HS \\
\hline 5220 & Horakani & 77.33 & 9 & HS \\
\hline 5221 & Kalisura & 74.33 & 9 & HS \\
\hline 5222 & Akra & 57.33 & 7 & HS \\
\hline 5223 & Ushi har & 66.00 & 9 & HS \\
\hline 5250 & Ashfuli & 75.00 & 9 & HS \\
\hline 5286 & Ranisalut & 61.66 & 7 & HS \\
\hline 5289 & Buripagli & 68.00 & 9 & HS \\
\hline 5298 & Harisankar & 67.66 & 9 & HS \\
\hline 5300 & Birinde & 84.66 & 9 & HS \\
\hline 5310 & Orgoja & 11.66 & 1 & $\mathrm{R}$ \\
\hline 5316 & Nonamurchi & 71.66 & 9 & HS \\
\hline
\end{tabular}

8 Parveen et al 
Table 4. Continued.

\begin{tabular}{lcccc}
\hline Acc. no. & Variety & RLH $(\%)$ & SES score & Reaction \\
\hline 5319 & Gandhakusturi & 64.66 & 9 & HS \\
5327 & Huglapata & 76.66 & 9 & HS \\
5329 & Gota & 89.66 & 7 & HS \\
5330 & Dorkumur & 48.33 & 9 & HS \\
5337 & Changi & 72.00 & 7 & HS \\
5345 & Rasasail & 62.33 & 9 & HS \\
5347 & Sackhorkhana & 57.33 & 9 & HS \\
-- & BR11 & 90.66 & & HS \\
\hline LSD (P=0.05) & & 17.52 & & \\
\hline
\end{tabular}

MT=Moderately tolerant, $\mathrm{HS}=$ Highly susceptible, $\mathrm{R}=$ Resistant.

inoculation method (Fig. 2). In general, dwarf, short duration and photo insensitive varieties were more susceptible to ShB. Prasad and Eizenga (2008) tested 73 Oryza genotypes for identifying resistant sources. They found only seven accessions moderately resistant to ShB. On the other hand, Moni (2012) found no resistant variety against ShB.

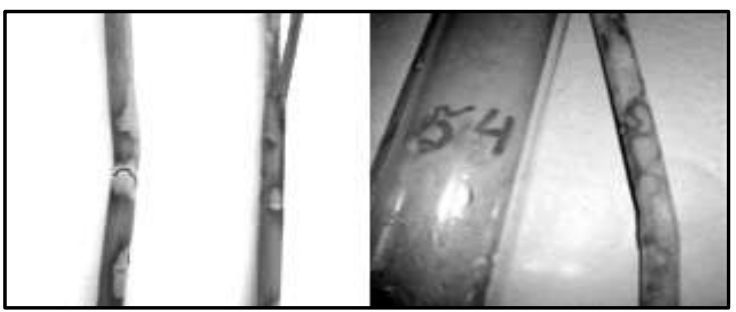

a) BR11

b) Dorkumur

Fig. 2. ShB symptoms of BR11 and Dorkumur due to artificial inoculation of Rhizoctonia solani through detached sheath inoculation method in test tube.

\section{Integrated management of ShB of rice}

Table 5 shows that the integrated management packages of ShB of rice resulted profound effect. Relative lesion height (RLH) was the maximum (68\%) in $\mathrm{T}_{6}$ (Control). The minimum RLH was $8 \%$ in $\mathrm{T}_{1}(\mathrm{FDR}+30$ July planting + Potash (K) fertilizer (202 $\left.\mathrm{g} \mathrm{decimal}^{-1}\right)+$ top dressing of urea (247 $\left.\mathrm{kg} \mathrm{ha}^{-1}\right)$ in four equal splits at 15 days interval + single spray of fungicide) and $\mathrm{T}_{3}$ (K-dose + top dressing of urea in four equal splits at 15 days interval + single spray of fungicide). RLH was significantly different in different treatment combinations. $\mathrm{T}_{2}$ (30 July planting $+\mathrm{K}$-dose + top dressing of urea in four equal splits at 15 days interval + single spray of fungicide) and
$\mathrm{T}_{3}$ (K-dose + top dressing of urea in four equal splits at 15 days interval + single spray of fungicide) significantly differed in RLH. $T_{4}$ (Top dressing of urea in four equal splits at 15 days interval + single spray of fungicide) and $\mathrm{T}_{5}$ (Single spray of fungicide) was different in RLH. Difference between $T_{3}$ and $T_{4}$ in RLH was also significant. There was significant difference in PDI (Percent disease index) among the treatment combinations. The maximum PDI was $69 \%$ in $\mathrm{T}_{6}$ and the minimum $5 \%$ in $\mathrm{T}_{1} . \mathrm{T}_{2}$ and $\mathrm{T}_{3}$ also differed significantly. Similarly, PDI of $\mathrm{T}_{4}$ differed significantly from that of $\mathrm{T}_{5}$. Moreover, tiller infection was $5 \%$ in $\mathrm{T}_{1}$ which was significantly different from $\mathrm{T}_{2}$ with $17 \% . \mathrm{T}_{3}$ and $\mathrm{T}_{4}$ were also different in tiller infection. There was $25 \%$ tiller infection in $\mathrm{T}_{4}$ and $39 \%$ in $\mathrm{T}_{5}$. The maximum tiller infection was $86 \%$ in $\mathrm{T}_{6}$. Besides, hill infection was $79 \%$ in $\mathrm{T}_{6}$ (Control) as compared to $47 \%$ in $\mathrm{T}_{5}$ (Single spray of fungicide). The difference was significant. In $\mathrm{T}_{1}$ only $3 \%$ of the hills became infected, but it was $15 \%$ in $\mathrm{T}_{2}, 19 \%$ in $\mathrm{T}_{3}$ and $35 \%$ in $\mathrm{T}_{4}$ and all the treatments differed significantly.

Table 5. Effect of integrated disease management (IDM) on ShB of BR11 rice variety during T. Aman 2013.

\begin{tabular}{lcccc}
\hline Treatment & $\begin{array}{c}\text { RLH } \\
(\%)\end{array}$ & $\begin{array}{c}\text { PDI } \\
(\%)\end{array}$ & $\begin{array}{c}\text { Tiller } \\
\text { infection } \\
(\%)\end{array}$ & $\begin{array}{c}\text { Hill } \\
\text { infection } \\
(\%)\end{array}$ \\
\hline $\mathrm{T}_{1}$ & $8 \mathrm{f}$ & $5 \mathrm{f}$ & $5 \mathrm{f}$ & $3 \mathrm{f}$ \\
$\mathrm{T}_{2}$ & $17 \mathrm{e}$ & $16 \mathrm{e}$ & $17 \mathrm{e}$ & $15 \mathrm{e}$ \\
$\mathrm{T}_{3}$ & $23 \mathrm{~d}$ & $25 \mathrm{~d}$ & $21 \mathrm{~d}$ & $19 \mathrm{~d}$ \\
$\mathrm{~T}_{4}$ & $36 \mathrm{c}$ & $39 \mathrm{c}$ & $25 \mathrm{c}$ & $35 \mathrm{c}$ \\
$\mathrm{T}_{5}$ & $49 \mathrm{~b}$ & $51 \mathrm{~b}$ & $39 \mathrm{~b}$ & $47 \mathrm{~b}$ \\
$\mathrm{~T}_{6}$ & $68 \mathrm{a}$ & $69 \mathrm{a}$ & $86 \mathrm{a}$ & $79 \mathrm{a}$ \\
\hline
\end{tabular}

Means followed by the same letter in a column did not differ significantly at the $5 \%$ level by LSD. 
Table 6 shows that the effect of integrated management of ShB on yield and yield components. The maximum number of panicles per $\mathrm{m}^{2}$ was recorded in $\mathrm{T}_{1}(260)$ and the minimum in $\mathrm{T}_{6}$ (Control) (227). There was no difference between $T_{5}$ (231) and $T_{6}$. However, the number of panicles per $\mathrm{m}^{2}$ was 251 in $\mathrm{T}_{2}, 245$ in $\mathrm{T}_{3}, 238$ in $\mathrm{T}_{4}$ and 231 in $\mathrm{T}_{5}$ and all the treatments differed significantly. Number of filled grains per panicle was also significantly different in different treatments. It was 150 and 145 in $T_{1}$ and $T_{2}$. The minimum number of filled grains per panicle was recorded in $\mathrm{T}_{6}$ (120) which differed significantly for that in $T_{5}$ (125). Significant difference was also observed between $\mathrm{T}_{3}$ (139) and $T_{4}$ (131). Number of unfilled grains was the lowest in $\mathrm{T}_{1}$ and the maximum in $\mathrm{T}_{6}$. Significant difference was also observed between $T_{3}$ and $T_{4}$ as well as $T_{5}$ and $T_{6}$. Similarly, difference between $T_{4}$ and $T_{5}$ was also significant in number of unfilled grains per panicle. But there was no effect of integrated management of ShB on grain size. Weight of 1000 grain was $20 \mathrm{~g}$ in all treatments. Significant difference was observed between the treatments in grain yield of rice due to integrated management of ShB disease. The maximum yield was recorded in $\mathrm{T}_{1}\left(6.3 \mathrm{t} \mathrm{ha}^{-1}\right)$ and the minimum in $\mathrm{T}_{6}\left(3.6 \mathrm{tha}^{-}\right.$ 1). Yield was $6.0 \mathrm{t} \mathrm{ha}^{-1}$ in $T_{2}$ as compared to $5.5 \mathrm{t}$ ha $^{-1}$ in $T_{3}$ and the difference was significant. Similarly, $\mathrm{T}_{4}$ produced $5.2 \mathrm{t} \mathrm{ha}^{-1}$ which was significantly lower than that of $T_{5}$ (4.5).

Finally, the present study revealed that the best IDM package was $\mathrm{T}_{1}$ which included removal of floating debris, transplanting on 30 July, potash (K) fertilizer (202 $\left.\mathrm{g} \mathrm{decimal}^{-1}\right)$, urea top dressing $\left(247 \mathrm{~kg} \mathrm{ha}^{-1}\right)$ in four equal splits at 15 days interval and single spray of Azoxystrobin (10\%) + Tebuconazole $(90 \%)$ combination. Because, the maximum RLH, PDI, tiller infection and hill infection were found in control plot $\left(\mathrm{T}_{6}\right)$, whereas it was lower in the IDM packages and minimum in $\mathrm{T}_{1}$ plot. Grain yield was also significantly higher in the IDM plots due to minimum incidence of ShB. Because, ShB was very low and grain yield was maximum in the plots where IDM was applied against $\mathrm{ShB}$ of rice due to its trace infection. Therefore, it can be concluded that the IDM package $\left(T_{1}\right)$ though highly effective to control ShB of rice, but the result needs validation across the ecosystem. However, Rhizoctonia solani is an universal soil borne facultative and epidemic pathogen. The pathogen is difficult to control unless control measure is taken on time. Many scientists narrated that a single method of control is not effective in most cases to control ShB but IDM is recommended by the researchers (Mew et al., 2004). Host resistance is a sustainable and economic method but there is no such resistant cultivar (Groth et al., 1993). Antagonist such as Trichoderma may be a good option to include in IDM package (Dey et al., 2004). ShB infection at flowering stage reduce grain yield due to higher amount of unfilled grains ( $\mathrm{Cu}$ et al., 1996) as because of damage of leaf sheath by the disease, affect water and nutrients supply to the growing spikelets (Lee and Rush, 1983).

Table 6. Effect of IDM on yield and yield components of BR11 during T. Aman 2013.

\begin{tabular}{lccccc}
\hline Treatment & $\begin{array}{c}\text { Panicle } \\
\text { per } \mathrm{m}^{2}\end{array}$ & $\begin{array}{c}\text { Filled } \\
\text { grain } \\
\text { panicle }\end{array}$ & $\begin{array}{c}\text { Sterile } \\
\text { pikelet } \\
\text { panicle }\end{array}$ & $\begin{array}{c}\text { TGW } \\
(\mathrm{g})\end{array}$ & $\begin{array}{c}\text { Yield } \\
\left(\mathrm{t} \mathrm{ha}^{-1}\right)\end{array}$ \\
\hline $\mathrm{T}_{1}$ & $260 \mathrm{a}$ & $150 \mathrm{a}$ & $40 \mathrm{f}$ & 20 & $6.25 \mathrm{a}$ \\
$\mathrm{T}_{2}$ & $251 \mathrm{~b}$ & $145 \mathrm{~b}$ & $47 \mathrm{e}$ & 20 & $6.00 \mathrm{~b}$ \\
$\mathrm{~T}_{3}$ & $245 \mathrm{c}$ & $139 \mathrm{c}$ & $53 \mathrm{~d}$ & 20 & $5.52 \mathrm{c}$ \\
$\mathrm{T}_{4}$ & $238 \mathrm{~d}$ & $131 \mathrm{c}$ & $61 \mathrm{c}$ & 20 & $5.15 \mathrm{~d}$ \\
$\mathrm{~T}_{5}$ & $231 \mathrm{e}$ & $125 \mathrm{~d}$ & $67 \mathrm{~b}$ & 20 & $4.49 \mathrm{e}$ \\
$\mathrm{T}_{6}$ & $227 \mathrm{e}$ & $120 \mathrm{e}$ & $61 \mathrm{a}$ & 20 & $3.60 \mathrm{f}$ \\
Significance & $*$ & $*$ & & & $*$ \\
$\mathrm{CV}(\%)$ & 5.15 & 8.65 & 18.40 & 0.0 & 19.16 \\
LSD 0.05 & 4.00 & 3.50 & 4.90 & $\mathrm{NS}$ & 0.22 \\
\hline
\end{tabular}

Means followed by the same letter did not differ at the 5\% level by LSD. NS=Not significant. TGW=1000 grain weight 


\section{CONCLUSIONS}

$\mathrm{ShB}$ of rice is considered as one of the major constraints of rice production in Bangladesh. Almost all HYVs and hybrid varieties are susceptible to the disease. Method for controlling the disease is an urgent need. Among the 57 germplasms, the local cultivar Orgoja (acc. no. 5310) showed resistance to ShB in both hill inoculation in field and detached sheath inoculation in test tube, which could be used in resistance breeding for varietal improvement programme of rice. On the other hand, the best integrated disease management (IDM) package was $\mathrm{T}_{1}$ which included removal of floating debris, transplanting on 30 July, potash (K) fertilizer (202 $\left.\mathrm{g} \mathrm{decimal}^{-1}\right)$, top dressing of urea $\left(247 \mathrm{~kg} \mathrm{ha}^{-1}\right)$ in four equal splits at 15 days interval and single spray of Azoxystrobin (10\%) + Tebuconazole (90\%) combination. Because, ShB was very low and grain yield was high in the plots where $T_{1}$ package was applied. Therefore, it can be concluded that the IDM package $\left(\mathrm{T}_{1}\right)$ though highly effective to control ShB of rice, but the result needs validation in the farmer's field in different seasons with different rice varieties across the different AEZs of Bangladesh.

\section{ACKNOWLEDGEMENTS}

This study was the part of the corresponding author's PhD dissertation. The author acknowledges the scholarship and financial support given by NATP, BARC, Dhaka and research facilities provided by Plant Pathology Division, BRRI, Gazipur.

\section{REFERENCES}

AIS (Agricultural Information Service). 2019. Krishi Diary 2019, Agricultural Information Service, Khamarbari, Farmgate, Dhaka 1215, Bangladesh. www.ais.gov.bd.
Ali, M A, M M Rahman, M A Latif, M Hossain, N R Sharma, S Akter, T A Mia and M A Nahar. 2003. Survey of rice sheath disease caused by different Rhizoctonia sp. in Bangladesh. In: Paper presented in the stakeholder workshop on Rice sheath blight disease complex, 3 December 2003. BRRI, Gazipur.

Anonymous. 1996. Standard Evaluation System for Rice. The International Rice Research Institute, Los Banos, Laguna, Philippines. p. 64.

Anonymous. 2007. Modern Rice Cultivation (Adhunik Dhaner Chas-Bangla version). Publication no. 5, 13 th Edition. Bangladesh Rice Research Institute, Gazipur 1701.

Anonymous. 2010. Modern Rice Cultivation (Adhunik Dhaner Chas-Bangla version). Publication no. $5,15^{\text {th }}$ Edition. Bangladesh Rice Research Institute, Gazipur 1701.

Ashrafuzzaman, M H, M Jalaluddin, M I Kha1il and I Hossain. 2005. Integrated management of sheath blight of Aman rice. Bangladesh J. Plant. Pathol. 21 (1 and 2): 53-58.

BBS. 2018. Statistical Pocket Book Bangladesh 2017. Bangladesh Bureau of Statistics, Statistics and Informatics Division, Ministry of Planning, Govt. of the People's Republic of Bangladesh.

Bhaktavatsalam, G, K Satyanarayana, A P K Reddy and V T John. 1978. Evaluation for sheath blight resistance in rice. Int. Rice Res. Newsl. 3: 9-10.

CRRI. 1977. Annual report. Central Rice Research Institute, Cuttack, India.

Cu, R M, T W Mew, K G Cassman and P S Teng. 1996. Effect of sheath blight on yield in tropical, intensive rice production system (in Chinese). Plant Disease. 80: 1103-1108.

Damicone, J R, M V Patel and W F Moore. 1993. Density of sclerotia of Rhizoctonia solani and incidence of sheath blight in rice fields in Mississippi. Pl. Dis. 77(3): 257260.

Dasgupta, M K. 1992. Rice sheath blight: the challenge continues. Plant diseases of International Importance. 1: 130-157.

Dey, N. 2014. Harnessing the potential of indigenous rice lines: an issue of food sovereignty. In: J A Francis (ed.). CTA 2014. Department of Biotechnology, Visva-Bharati, Santiniketan, India.

Dey, R, K K Pal, D M Bhatt and S M Chauhan. 2004. Growth promotion and yield enhancement of peanut (Arachis hypogaea L.) by application of plant growth-promoting rhizobacteria. Microbiological Research. 159: 371-394.

Ganie, S A, J Karmakar, R Roy Chowdhury, T K Mondal and N Dey. 2014. Assessment of genetic diversity in salt-tolerant rice and its wild relatives for ten SSR loci and one allele mining primer of saltol gene located on 1st chromosome. Plant Systematics and Evolution (DOI 10.1007/s00606-014-0999-7, Published online). 
Groth, D and F Lee. 2002. Rice disease. In: W E Smith and R H Dilday (eds.). Rice: Origin, history, technology, and production. John Wiley and Sons, Hoboken, NJ. pp. 413-436.

Groth, D E, M C Rush, G G Giesler and C A Hollier. 1993. Foliar fungicides for use in the management of rice diseases. La. Agric. Exp. Stn. Bull. No. 840.

Hashiba, T and T Kobayashi. 1996. Rice diseases incited by Rhizoctonia species. In: B Sneh, S Jabaji-Hare, S Neate and G Dijst (eds.). Klewer Rhizoctonia species: Taxonomy, Molecular Biology, Ecology, Pathology and Disease Control. Academic Publisher, The Netherlands. pp. 331-340.

Hossain, M and M A T Mia. 2001. Management of sheath blight disease of rice under farmer's field condition. Bangladesh J. Plant. Pathol. 17 (1 and 2): 13-16.

Jalaluddin, M, M A Kashem, M K Hasna and M I Khalil. 2000. Screening of some somaclonal progenies of rice for resistance to sheath blight and bacterial leaf blight. Crop Sci. 11 (1 and 2): 39-42.

Karmakar, J, R Roychowdhury, R K Kar, D Deb, N Dey and H S Srivastava. 2012. Profiling of selected indigenous rice (Oryza sativa L.) landraces of Rarh Bengal in relation to osmotic stress tolerance. Physiology and Molecular Biology of Plants. 18(2): 125-132.

Lee, F N and M C Rush. 1983. Rice sheath blight: A major rice disease. Plant Disease. 67 (7): 829-32.

Li, Di-q, Q-y Tang, Y-b Zhang, J-q Qin, H Li, L-j Chen, S-h Yang, Y-b Zou and S-b Peng. 2012. Effect of nitrogen regimes on grain yield, nitrogen utilization, radiation use efficiency, and sheath blight disease intensity in super hybrid rice. Journal of Integrative Agriculture. 11: 134-143.

Mahbub, A M, M Hossain and A Janaich. 2001. Hybrid rice adoption in Bangladesh. A socioeconomic assessment of farmer's experience: Research Monograph. Series no. 18. Social Science Division, International Rice Research Institute (IRRI), Los Banos, Laguna, Philippines. p. 38.

McKinney, H H. 1923. A new system of grading plant diseases. Journal of Agriculture Research 26: 195218.
Mew, T W, H Leung, S Savary, C M V Cruz and J E Leach. 2004. Looking ahead in rice disease research and management. Critical Reviews in Plant Science. 23: 103-127.

Miyakie, I. 1910. Studies über die Pilze der Reispflanzen in Japan. J. Coll. Agric. 2: 237-276.

Moni, Z R. 2012. Biological characterization and management of Rhizoctonia solani causal organism of rice sheath blight disease. PhD thesis, Department of Botany, University of Rajshahi, Rajshahi, Bangladesh.

Parveen, S. 2016. Management of sheath blight disease of rice. PhD thesis, Department of Genetics and Plant Breeding, BAU, Mymensingh, Bangladesh. p. 58.

Prasad, B and G C Eizenga. 2008. Rice sheath blight disease resistance identified in Oryza spp. accessions. Plant Dis. 92: 1503-1509.

Rao, K M. 1995. Sheath blight disease of rice. Daya Publishing House, Delhi-110035.

Roychowdhury, R, J Karmakar, M K Adak, N Dey and A Mitra. 2013. Physio-biochemical and microsatellite based profiling of lowland rice (Oryza sativa L.) landraces for osmotic stress tolerance. American Journal of Plant Sciences. 4(12C): 52-63.

Salam, M U, S M A Hossain, J K Biswas and A J Mridha. 2014. Managing the unmanageable: rice variety technology for future challenging food security in Bangladesh. Extended abstract in the Agronomic visions in challenging future, the proceedings of the $13^{\text {th }}$ conference of the Bangladesh Society of Agronomy, 20 September 2014, Bangladesh Rice Research Institute (BRRI), Gazipur, Bangladesh.

Shahjahan, A K M, N R Sharma, H U Ahmed and S A Miah. 1986. Yield loss in modern rice varieties of Bangladesh due to sheath blight. Bangladesh J. of Agricutural Research. 11(2): 82-90.

Sharma, N R and P S Teng. 1990. Effects of inoculum source on sheath blight development. Int. Rice Res. Newsl. 15: 18-19.

Wu, W, J Huang, K Cui, L Nie, Q Wang, F Yang, F Shah, F Yao and S Peng. 2012. Sheath blight reduces stem breaking resistance and increases lodging susceptibility of rice plants. Field Crops Research. 128: $101-10$ 